\title{
Review and Recommendations for Renewable Energy Policies and Regulations to Promote Private Investment in Liberia
}

\author{
Omar V. Al Sherif \\ Independent Researcher \\ Email: omarsherro[at]yahoo.com
}

\begin{abstract}
The development and implementation of renewable energy policies and regulations in Liberia are cardinal to develop the nascent electricity sector. Liberia had developed some of the priority policy and regulatory instruments in the electricity sector; however, supportive policies and regulations to minimize investment risks and create an enabling environment for all actors are indispensable to attain universal energy access. The research aims to provide policy and regulatory recommendations that will increase private sector participation in the electricity sector of Liberia through the deployment of renewable energy technologies. The recommendations examined a comprehensive review and analysis of the energy legislation in Liberia, renewable energy policies in Nigeria, Ghana, Sierra Leone, and data on renewable energy policies from countries in West Africa. It was explicit from the literature review that Liberia does not have policies and regulations for renewable power generation, transmission, and distribution, which are imperative for private sector participation. The establishment of the new renewable energy law and supportive policies such as policy and regulation on tariff setting, fiscal policy, financial policy, administrative and legal provisions, and technical standards are the recommendations of this research paper.
\end{abstract}

Keywords: Renewable energy, Renewable power generation, Policy, Regulation, Electricity

\section{Introduction}

The contribution of renewable power capacity in the global power generation mix has proven to be a significant and established source of clean power generation supply to meet the world's growing energy demand in the power sector (REN21, 2019). For instance, in the power sector, solar PV generation capacity's deployment accounts for $55 \%$ of all the renewable capacity added in 2018 (REN21, 2019). The major contributing factors to the acceleration in renewable power generation are the stabile policies implementation and the adoption of targets at all levels (REN21, 2019).

The private sector participation in the power generation sector is critical to earning the social-economic benefits of renewable power deployment and promoting universal clean energy access. In the absence of sound policy and regulatory frameworks that will mitigate investment risk, stimulate innovation, and promote competition, there will be low private sector involvement in deploying renewable energy technologies. However, several policies and regulations exist to guarantee competitiveness, transparency, and accountability for private sector participation. These policies and regulations vary from country to country, state to state, deployment approach, and capacity. Howbeit, there is no single policy or legislation that is effective and efficient to address the growing renewable power deployment and energy demand.

Liberia, Somalia, and Mozambique were the three countries with the lowest score in the Regulatory Indicators for Sustainable Energy (RISE) 2018 report (ESMAP, 2018). Despite the progress made in developing an enabling environment for the development and deployment of renewable energy technologies, the country still has substantial work to undertake in the power sector supply chain. Liberia has developed targets for renewable power generation with a nascent renewable energy sector, a dedicated agency for renewable energy planning, coordination and implementation, and an electricity regulatory body. The energy legislations and master plans available in Liberia are: National Energy Policy 2009 (NEP 2009), 2015 Electricity Law of Liberia, Rural Energy Strategy and Master Plan (RESMP), National Electrification Master Plan (2013), and the primary institutions for policy, strategic planning, and regulations in the energy sector are: Ministry of Mines and Energy (MME), Rural and Renewable Energy Agency (RREA), and the Liberia Electricity Regulatory Commission (LERC).

Notwithstanding, there are unclear policies and regulations to support either the deployment of renewable power for utility-scale or large scale plants, integration of large scale variable renewable power, decentralized grid-connected, mini-grid solutions, stand-alone off-grid solutions, or the combination of these options. Besides, there is inadequate private sector participation in the electricity sector due to the national utility's vertically integrated structure and the lack of supportive fiscal and financial policies and regulations.

The research paper provides a comprehensive review of Liberia's electricity legislation that promotes renewable energy technologies, policy development, and regulatory recommendations to support private-sector participation and increase energy access using renewable energy resources. The paper draws significant lessons from renewable energy policy development in West Africa, with specific experiences from Nigeria, Ghana, and Sierra Leone. Ghana was among the nine sub-Saharan African countries with a high electricity access policy score in the RISE 2018 report (ESMAP, 2018). 


\section{International Journal of Science and Research (IJSR) \\ ISSN: 2319-7064 \\ SJIF (2020): 7.803}

The methodology used in the research is a detailed review of the country's renewable energy policy and legislation, reports from international development institutions, and research papers on renewable energy policy and development. The literature review also highlights the regional energy policy and strategic plan to increase renewable power generation in West Africa.

The structure of the research paper includes: (i)a comprehensive analysis and literature review of the primary legislation in the electricity sector of Liberia and indicate renewable power policies and regulations, (ii) methodology detailing the procedures, (iii) data analysis of renewable power policy implementation in West Africa with case study from Nigeria, Ghana, and Sierra Leone, and (iv)discussion on the renewable energy deployment strength, weakness, opportunities and threats (SWOT) analysis of Liberia, and policies and regulatory recommendations.

\section{Background and Literature Review}

\subsection{Energy policy and Regulations in Liberia}

\subsubsection{National Energy Policy}

The National Energy Policy (NEP), published in 2009, is the core energy policy document upon which all legal, institutional, strategy plans, and other policies for Liberia arise (NEP, 2009). To ensure universal access to modern energy services in an affordable, sustainable, and environmentally-friendly manner and to foster the economic, political, and social development of Liberia, the NEP addresses four strategies issues, access, quality, cost, and institutional framework (NEP, 2009).

In achieving the overall policy objective and addressing the fundamental issues of access, quality, cost, and institutional frameworks, the NEP delineated measures to promote the development of various policies and regulations in the power sector. In the electricity sector statements of policy reforms, the NEP strongly endorsed the private sector participation in the generation, transmission, distribution, and electricity sales (NEP, 2009). Some of the policies and regulations that the NEP statements support are:

\subsubsection{Net metering/ Billing}

The NEP promotes self-power generation, consumption, and the sale of excess electricity produced by a private actor(s). One of the four main issues that NEP seeks to address is electricity access, and that unbundling the electricity sector also means providing access to the national grid. However, grid access in the NEP requires that the power generation facility operator must have generation and distribution licenses. Depending on the generation capacity and the regulator's threshold, the operator may have access to the grid without a permit but must register with the regulatory body envisioned in NEP and mandated in the current 2015 Electricity Law of Liberia (NEP, 2009).

\subsubsection{Feed-in Tariff and Feed-in Prime}

The NEP supports the long-term financial viability of investment in the power generation sector and recognized the long-run marginal cost (LRMC) analysis as a tool to develop the least cost power option. However, a study on the LRMC based electricity pricing indicates that an increasing share of renewable power generation will impact a price level in the day-ahead markets, creates high price volatility, and the need for alternative revenue sources for new investment (Pikk \& Viiding, 3 June 2014). The Levelized cost of electricity (LCOE) is one of the financial viability tools used to assess a renewable power investment. Nevertheless, where applicable, the LCOE and LRMC can serve as the tariff methodology, as is the case with the Nigerian regulations on Feed-in-Tariff for renewable electricity sources (NERC, 2015). Besides, the LCOE serves as the basis for tariff setting under the Feed-in Tariff and Feed-in Prime policy development (Couture, Cory, Kreycik, \& Williams, 2010). Because the Feed-in Tariffs policy supports realistic tariff setting and methodology, the NEP also enables private project developers with a suitable tariff setting in consultation with the regulator.

\subsubsection{Competitively price setting (Auction)}

The NEP mandates the regulatory authority to exercise and encourage free and transparent competition in the energy sector and explores affordable pricing options for different consumer categories. Based on the regulator's instrument, auctions in the electricity sector could be a means to attract more private investment in the deployment of renewable energy technologies in Liberia.

\subsubsection{Fiscal and Financial Incentives}

The NEP recognizes that access to off-grid power and renewable energy development requires incentives and financial provision. Some of the economic and financial instruments identified in the NEP are subsidies, grants, lowinterest loans, and special incentives (NEP, 2009).

\subsection{Renewable Energy Targets and Law}

Within the framework of developing institutions and legal provisions in the renewable energy and power sectors, the NEP proposed formulating the Rural and Renewable Energy Agency (RREA) (NEP, 2009). The RREA, established in 2010, is an autonomous agency that has the mandate to facilitate and accelerate the economic transformation of rural Liberia through the commercial development and supply of modern energy services using local renewable energy resources ${ }^{1}$. Based on the NEP institutional framework guidelines, the RREA published the Rural Energy Strategy and Master Plan (RESMP) for Liberia until 2030 in 2016 (GESTO, 2016). The NEP also proposed establishing the Electricity Law of Liberia and recommended the enactment of the 2015 Electricity Law of Liberia (NEP, 2009). The 2015 Electricity Law aims to facilitate the principal objective of the NEP and effectuated the legislation for the creation of the Liberia Electricity Regulation Commission (LERC) ${ }^{2}(2015$ Electricity Law of Liberia, 2015). LERC is an independent institution with the legal mandate to plan, regulate, and monitor the issuances of license(s) to an individual or entity wishing to participate in the electric power generation, transmission, and distribution

\footnotetext{
${ }^{1}$ https://rrealiberia.org/new/index.php

${ }^{2}$ https://www.mca.gov.lr/index.php/en/lerec-support
}

\section{Volume 10 Issue 7, July 2021}


sector as enshrined in the 2015 Electricity Law of Liberia (2015 Electricity Law of Liberia, 2015).

\subsection{Electricity Law of Liberia}

There are policies and legislation in the NEP and the 2015 Electricity Law that support renewable energy policy formulation on a prospective and ongoing basis. Besides, the enactment of the 2015 Electricity Law of Liberia facilitates the NEP objective's implementation (2015 Electricity Law of Liberia, 2015). Section 2.1(2) (4) of the 2015 Electricity Law explicitly underscores the need to attract private investment in the electricity sector and the promotion of renewable energy sources for power generation (2015 Electricity Law of Liberia, 2015). The primary policies and regulations development that the 2015 Electricity Law supports for private sector participation are:

\subsubsection{Legal Provision Policy}

Section 3.3 (A.3) allows the regulator to register a person that is not required to have a license with a given electricity generation capacity threshold. This section also provides the opportunity to support a legal provision policy to increase electricity access depicted in section 2.1 subsection (1). Furthermore, section 5.1(2) reinforces the need for a legal provision under a given threshold set by the regulator, but the person must register with the regulator. Section 5.7(2) also elaborated on license exemption or issuing a single license for all functions. With all these provisions in the 2015 law, developing a legal provision policy has a ruling to substantiate the policy development.

\subsubsection{Feed-in Tariffs (FiTs) Policy}

Section 8.1(1. a) supports the adoption of the FiTs on costrecovery basic. Subsections (2)(3) also provide the means for tariff adjustment, as is the case with the development of policy and Power Purchase Agreement (PPA) for FiTs. Section 8.2(3)(4) also explains the legal guideline to support FiTs under a PPA section 8.6. Since the FiTs guarantees a stable revenue from a project investment, section 8.1(1.a) supports full cost recovery and returns (2015 Electricity Law of Liberia, 2015).

\subsubsection{Tariff (Pricing Regulation Policy)}

Section 6.1(d) (e) of the 2015 Electricity Law provides the regulation for tariff moderation and price setting. These sections facilitate using a tariff/pricing regulation policy development to promote investment in renewable energy development (2015 Electricity Law of Liberia, 2015).

\subsubsection{Net-metering and Billing Policy}

Section 6.9(5) provides the legislative clause for the netmetering and billing system. Section 8.7 support net metering and billing as well. Hence, there is a legal provision to support the development of a net-metering and billing policy (2015 Electricity Law of Liberia, 2015).

\subsubsection{Fiscal and Financial Incentives Policy}

Section 8.11 supports incentives-based regulations such as the performance-based, generation-based incentives, and auctions. This section also facilitates the formulation of policies that support performance and generation-based incentives (2015 Electricity Law of Liberia, 2015).

\subsubsection{Grid Arrival Policy}

Section 9.4(1) mandates the national utility to provide access to the grid subject to terms and conditions in the 2015 electricity law. This section defines the means to develop a grid arrival policy.

\subsubsection{Competitively Pricing (Auction) Policy}

Section 2.1(11) upholds the use of the auction policy by efficiently promoting sustainable and fairs competition in the electricity sector. Section 8.11 also enables the auction process to gain affordable prices and boost competition (2015 Electricity Law of Liberia, 2015).

\subsection{Rural Energy Strategy and Master Plan}

The NEP also recommends the development of the Rural Energy Strategy Master Plan of Liberia as a fundamental tool to enhance the operation of the RREA in the development of prioritized programs to achieve universal energy access. The Rural Energy Strategy and Master Plan and the Grid Development Master Plan are the proposed roadmap to achieve the long-term plan of Liberia's National Energy Policy (NEP, 2009). Fundamentally, the RESMP provides all the renewable energy targets, programs, projects, and ambitious plans for Liberia until 2030 (GESTO, 2016).

\subsection{Research Gaps from the Energy Legislations}

The National Energy Policy, the 2015 Electricity Law of Liberia, and the Rural Energy Strategy Master Plan are the current legislations that primarily support development in renewable energy technology. A conclusion based on an extensive review of the three legislations and the types of policy options that necessitate investment in renewable energy deployment is that Liberia does not have a specific policy on renewable power development. However, the three legislations promote energy investment, private participation, and targets for the deployment of hydropower, solar PV, and biomass.

Furthermore, the National Energy Policy and 2015 Electricity Law of Liberia implicitly support the various policy and regulatory options to deploy renewable energy technologies. Notwithstanding, neither the NEP nor the 2015 Electricity Law provides specific policy options to support a given technology. For instance, the adoption of Feed-in Tariffs to promote investment in hydropower or solar PV; or implementing a net-metering/billing policy to support investment in solar PV rooftop.

\section{Methodology}

The methodology considered in this research paper's development is an extensive review of the literature on renewable power policy development and implementation in selected countries in West Africa. The author used compiled data on renewable power policy in West Africa to summarize development and adoption trends. Renewable 


\section{International Journal of Science and Research (IJSR) ISSN: 2319-7064 \\ SJIF (2020): 7.803}

power policy design is country-specific, and there are several factors to consider in policy development, including institutional capacity, market structure, utility credibility, financing sources, and local expertise. To make an informed policy instruments recommendations for Liberia, the author used the Strength, Weakness, Opportunities Threats (SWOT) analysis to assess the country's renewable energy development trends. The SWOT analysis is prevalent in strategic and cooperate planning, marketing, and social development (Gurel \& Tat, 2017). However, the SWOT analysis has been used for research on renewable energy development in eastern Asia ( Wei-Ming, Hana, \& Hideka, 2014), to identify the current status and the future of renewable energy sector (Kamran, Fazal, \& Mudassar, 2019), and to assess the drivers and barriers of renewable energy in countries high deployment pace (Elavarasan, Afridhis, Vijayaraghavan, Subramaniam, \& Nurunnabi, 2020).

\section{Data Analysis}

\subsection{Development of RE power in West Africa}

\subsubsection{Renewable Energy Policy in West Africa}

The Economic Community of West African States (ECOWAS) Renewable Energy Policy (EREP) adopted in 2013 aims to increase the use of renewable energy sources, including solar, wind, small-scale hydro, bioenergy for grid electricity supply, and the provision of access to energy services in rural areas (ECREEE, 2013). The West African Power Pool (WAPP) Master Plan and the EREP aim to increase the share of renewable energy supply in the energy generation mix for grid-connected electricity at $23 \%$ in $2020,31 \%$ in 2030 (IRENA, 2018), and the off-grid energy mix target at $22 \%$ in 2020 , $25 \%$ in 2030 (ECREEE, 2013). The WAPP goal is to promote and develop power generation and transmission infrastructures and power exchange among the ECOWAS member states ${ }^{3}$. The ECOWAS Energy Protocol A/P4/1/03 creates a legal framework to promote co-operation in the energy sector of West Africa based on complementarities and mutual benefits and to increase investment and energy trade in the region (ECOWAS, 2003).

Given the commitment and ambitious plans to accelerate investment and deployment of renewable energy technologies in West Africa, countries in the region have established targets to increase the share of renewable in the national energy mix and market policies for private sector participation and investment risk mitigation. All the countries in West Africa have renewable energy targets for power generation (REN21, 2019). Table 1 shows the current policies and regulations to promote electricity from renewable sources in West Africa ${ }^{4}$.

Burkina Faso, Ghana, Nigeria, and Senegal are the countries in West Africa with the most renewable energy policies and regulations development. Nigeria and Senegal were among the top 10 countries in Sub-Saharan African with policy introduction (Climatescope, 2020). The leading policy instruments adopted by most countries in the region are fiscal incentives, tendering, administrative, and legal provision

\begin{tabular}{|c|c|c|c|c|c|c|c|c|c|c|}
\hline \multirow[b]{3}{*}{ Countries } & \multicolumn{9}{|c|}{ Renewable Power Policies in West Africa } & \\
\hline & \multicolumn{6}{|c|}{ Regulatory Policies } & \multicolumn{4}{|c|}{ Fiscal Incentives and Public Financing Policies } \\
\hline & $\begin{array}{c}\text { Feed in } \\
\text { Tariff/ } \\
\text { Premiu } \\
\mathrm{m} \\
\text { payment }\end{array}$ & $\begin{array}{c}\text { Electric } \\
\text { Utility } \\
\text { Quota } \\
\text { Obligatio } \\
\text { n }\end{array}$ & $\begin{array}{c}\text { Net } \\
\text { Metering } \\
/ \\
\text { Billing }\end{array}$ & $\begin{array}{l}\text { Tendering } \\
\text { Call for } \\
\text { Proposal } \\
\text { competitiv } \\
\text { e process }\end{array}$ & $\begin{array}{l}\text { Administrativ } \\
\text { e \& legal } \\
\text { provisions } \\
\text { (connection } \\
\text { codes, tariff, } \\
\text { licensing, } \\
\text { etc.) }\end{array}$ & $\begin{array}{c}\text { Grid arrival } \\
\text { plan/strateg } \\
\text { y }\end{array}$ & $\begin{array}{c}\text { Investmen } \\
\mathrm{t} \text { or } \\
\text { productio } \\
\mathrm{n} \text { tax } \\
\text { credit }\end{array}$ & $\begin{array}{l}\text { Reductio } \\
\text { n in sales, } \\
\text { energy, } \\
\text { C02, } \\
\text { VAT, or } \\
\text { other } \\
\text { taxes }\end{array}$ & $\begin{array}{c}\text { Energy } \\
\text { productio } \\
\text { n payment }\end{array}$ & $\begin{array}{c}\text { Public } \\
\text { Investmen } \\
\text { t loan } \\
\text { grants, } \\
\text { capital } \\
\text { subsidies } \\
\text { or rebates }\end{array}$ \\
\hline Benin & & & & * & $*$ & & & $*$ & & \\
\hline Burkina Faso & & & & $*$ & $*$ & $*$ & $*$ & $*$ & $*$ & $*$ \\
\hline Cape Verde & & & $*$ & $*$ & & & & & $*$ & \\
\hline Cote D'Ivoire & & & & $*$ & $*$ & $*$ & & $*$ & & \\
\hline Gambia & & & & * & * & & & * & & \\
\hline Ghana & $*$ & $*$ & $*$ & $*$ & $*$ & & & * & & $*$ \\
\hline Guinea & & & & & & & & $*$ & & \\
\hline $\begin{array}{l}\text { Guinea - } \\
\text { Bissau }\end{array}$ & & & & $*$ & & & & & & \\
\hline Liberia & & & & & & & & * & & \\
\hline Mali & & & & $*$ & & & & $*$ & & * \\
\hline Niger & & & & $*$ & & & & $*$ & & \\
\hline Nigeria & $*$ & & & $*$ & $*$ & $*$ & & * & & $*$ \\
\hline Senegal & * & $*$ & $*$ & $*$ & & & & $*$ & & * \\
\hline
\end{tabular}

${ }^{3} \mathrm{https} / / / \mathrm{www}$. ecowapp.org/en/content/creation-wapp

${ }^{4}$ Author's compilation REN 2019

Volume 10 Issue 7, July 2021 www.ijsr.net 
International Journal of Science and Research (IJSR)

ISSN: 2319-7064

SJIF (2020): 7.803

\begin{tabular}{|l|l|l|l|l|l|l|l|l|l|} 
Sierra Leone & & & $*$ & $*$ & $*$ & $*$ & $*$ & & \\
\hline Togo & & & & $*$ & & & & & \\
\hline
\end{tabular}

4.1.2 Renewable Power Policy and Regulations in Nigeria, Sierra Leone, and Ghana

\subsubsection{Nigeria}

The Nigerian Electricity Regulatory Commission Mini-Grid Regulation, 2016, provides the regulation for mini-grid power generation deployment with a capacity of up to $1 \mathrm{MW}$ (Nigerian Electricity Regulatory Commission, 2016). The regulation addresses the concerns of the mini-grid stakeholders', owners, operators, end-users, public, private, distribution licensees, federal or state agencies, as well as technical and non-technical issues on mini-grid deployment. The two types of mini-grid structure or arrangement in the regulation are isolated mini-grid and interconnected minigrid.

\section{Grid arrival}

The mini-grid regulation provides two solutions when the distribution licensee's network extends to the geographical area of an isolated mini-grid permit holder. Either the isolated mini-grid converts to an interconnected mini-grid operator or receive compensation for all the assets based on the terms and conditions prescribed in the regulations (NERC, 2016).

\section{Administrative and legal Provision (License, tariff, etc.) Policy}

Isolated mini-grids below $100 \mathrm{~kW}$ of distributed power can either apply for a permit or register with the regulatory commission. Isolated mini-grids with a capacity above $100 \mathrm{~kW}$ of distributed power capacity and a maximum generation capacity of $1 \mathrm{MW}$ must have a license based on the commission's guidelines (Nigerian Electricity Regulatory Commission, 2016).

In the case of an interconnected mini-grid distributed power generation, there will be a tripartite contract with the minigrid operator, connected community, and distribution licensee with the approval of the commission under the terms and conditions of the regulation. The tripartite agreement will provide information on construction and ownership of additional infrastructure, tariff setting, power reliability, and voltage stability. The mini-grid permit holder must comply with all the technical code and standards, terms, and conditions stipulated by the commission (Nigerian Electricity Regulatory Commission, 2016).

The mini-grid permit holder can determine the tariffs using the Multi-Year Tariff Order (MYTO) calculation tool subject to a maximum of $10 \%$ technical and non-technical losses with the approval of the commission (Nigerian Electricity Regulatory Commission, 2016). Also, a registered mini-grid operator can either determine a tariff under the mini-grid permit holder's conditions or negotiate with the community on a reasonable electricity tariff subject to the commission approval.

Fiscal and Financial Policy (tax incentives)

National Renewable Energy and Energy Efficiency Policy (NREEEP) of Nigeria provide fiscal and financial incentives for renewable energy and energy efficiency development. The financial incentives are soft loans from development finance agencies with special annual interest not more than $5 \%$, subsidies and grants up to $30 \%$ of the initial investment, and sponsored capacity building (NREEEP, 2014). The fiscal incentives allow cooperate organizations to make a $50 \%$ payment of the profit tax at the prevailing rate and tax holidays for new companies for a minimum of 10 years of operation(NREEEP, 2014). Besides, the fiscal incentives policy also promote a reduction in import duty, and investment capital allowance of $20 \%$ per year for the first four years, $19 \%$ in the 5 th year, with $1 \%$ retained in the books, capital relief, and waiver of purchase taxes (NREEEP, 2014).

\section{Feed-in Tariff Policy}

In 2015, the Nigerian Electricity Regulatory Commission approved the Regulations on Feed-in Tariff for Renewable Energy Sourced Electricity in Nigeria with a minimum generation capacity of 2,000 MW by 2020 (NERC, 2015). The Feed-in Tariff (FiT) regulations are for investment in solar, small hydro, biomass, and wind technologies with capacities between $1 \mathrm{M}$ to $30 \mathrm{MW}$ (NERC, 2015). Below $1 \mathrm{M}$ capacity generation will have a net-metering procurement option, and above 30MW capacities will be through a competitive procurement process (NERC, 2015). The maximum generation capacities under the FiT regulations for solar, wind, biomass, and small are 5MW, 10MW, 10MW, and 30MW respectively (NERC, 2015). The Long Run Marginal Cost (LRMC) and the Levelised Cost of Energy (LCOE) are the tariff methodologies proposed for the feed-in tariff setting for the qualifying technologies (NERC, 2015). The PPA under the FiT regulations will have a term of 20 years from the commercial operation date (NERC, 2015).

\subsubsection{Sierra Leone}

The draft Sierra Leone Electricity and Water Regulatory Commission Mini-Grid Regulations, 2018, is the legislation that outlines the procedures for mini-grid deployment in the country (SLEWRC, 2018). It provides the guidelines requires by all the stakeholders in the mini-grid sector, state agencies, developers, and operators. The types of the minigrid structure defined in the regulation are isolated minigrid and interconnected mini-grid. A license granted can be either a basic mini-grid license or a full mini-grid license depending on the generation capacity (SLEWRC, 2018).

\section{Grid Arrival Policy}

In case the main grid arrives in a geographic location were the mini-grids operator has a basic licensee, the operator will decommission and remove all the assets within two months. The basic mini-grids license may receive compensation depending on the prevailing situation. However, for a full mini-grid licensee, the operator can either convert to an interconnected mini-grid or transfer the assets that the main grid utility wishes to retain for compensation base on the terms and conditions in the regulation (SLEWRC, 2018). 


\section{International Journal of Science and Research (IJSR) \\ ISSN: 2319-7064 \\ SJIF (2020): 7.803}

Administrative and legal Provision (License, tariff, etc.) Policy

The 2018 draft Mini-Grid Regulations grants a basic license to isolated mini-grids with a generation capacity up to $100 \mathrm{~kW}$ (SLEWRC, 2018). A full mini-grid license is issued for a generation capacity above $100 \mathrm{~kW}$ and up to $1 \mathrm{MW}$ inclusive (SLEWRC, 2018). Besides, the commission has the mandate to issues a full mini-grid license for interconnection with the main-grid utility in a location with lower power distribution. The mini-grids commissioned before the enforcement of the legislation have twelve months grace period to comply with the regulation.

\subsubsection{Ghana}

The Public Utilities Regulatory Commission (PURC) and the Energy Commission (EC) are the institutions that promote the development of energy policies and regulations in Ghana. The PURC regulates the provision of utility services in the electricity and water sectors, and provides guidelines, examines, and approve rate charged by the utilities. Besides, the PURC investigate, and settles disputes between consumers and public utility ${ }^{5}$. The EC provides the legal, regulatory and supervisory framework for all the energy stakeholders in Ghana, with the mandate to grant licenses for the transmission, wholesale, supply, distribution, and sale of electricity and natural gas and related matters ${ }^{6}$.

\section{Feed-in-Tariff}

The PURC published the Feed-in tariff (FiT) regulations in 2016 for electricity generated from renewable energy sources (PURC, 2016). The renewable energy technologies in the FiT regulation are Wind, Solar PV, Hydro, Tidal Wave (Ocean Wave), Run-of-River, Biomass, Landfill Gas, Sewage Gas, and Geoplutonic (Geothermal). The Power Purchase Agreement (PPA) signed under the FiT regulations will have a fixed and applicable rate for ten years (PURC, 2016), and a subsequent review every two years (REA, 2011). The electricity distribution utility cannot negotiate a PPA with and buy power from an electricity generator without the written assent of the PURC (REA, 2011).

\section{Electric utility quota obligation/RPS/ REC}

The Renewable Energy Act, 2011 obligate electricity distributor or bulk customer to procure a certain percentage of the total purchase electricity from renewable energy sources or pay a premium as determined by the commission (REA, 2011). Penalties are levy in case the electricity distributor or bulk customer fails to comply with the regulations set by the commission (REA, 2011).

\section{Net Metering}

The Net Metering Sub-code was introduced in 2015 by the Energy Commission to connect renewable energy generating systems to the distribution network in Ghana (Energy Commission, 2015). The net metering mechanism allows renewable energy generation facility owners to get credit for the supply of power to the grid and against the electricity purchased from the distribution utility. However,

\footnotetext{
${ }^{5}$ http://www.purc.com.gh/purc/features/fusion-menu

${ }^{6}$ http://www.energycom.gov.gh/about/mandate-and-functions
}

the amount of electricity supplied to the grid should not surpass the amount purchased over an annual tracking period (Energy Commission, 2015). The Net Metering subcode provides the guidelines and technical connection conditions for the inter-connection renewable power generation facility to the low voltage distribution network under the net metering scheme (Energy Commission, 2015).

\section{Results and Discussion}

\subsection{Renewable Power SWOT Analysis of Liberia}

In the SWOT analysis, strengths and weaknesses are internal factors of the organization or strategic plan; opportunities and threats are external factors that might impact the organization or strategic plan. Internal factors assess the strengths and weaknesses of the organization or strategic plan. The strengths identify the resource availability to enhance the performance of the organization or strategic plan, and weaknesses are the shortcomings that may decrease the competitive advantages, efficiency, or financial resources. The opportunities are external contributions that could bring more growth, and threats are external elements that may cause difficulties ( Wei-Ming, Hana, \& Hideka, 2014).

Hence, the SWOT analysis of the policy recommendations will evaluate the renewable energy deployment status, the electricity market structure, and the requirements for renewable power policy development. Figure 1 shows the SWOT analysis matrix for Liberia based on the review of reports and studies conducted with specific reference to the Regulatory Indicators for Sustainable Energy (RISE) 2018 report. Liberia, Somalia, Mozambique were among the three countries with the lowest score in the RISE 2017(ESMAP, 2018).

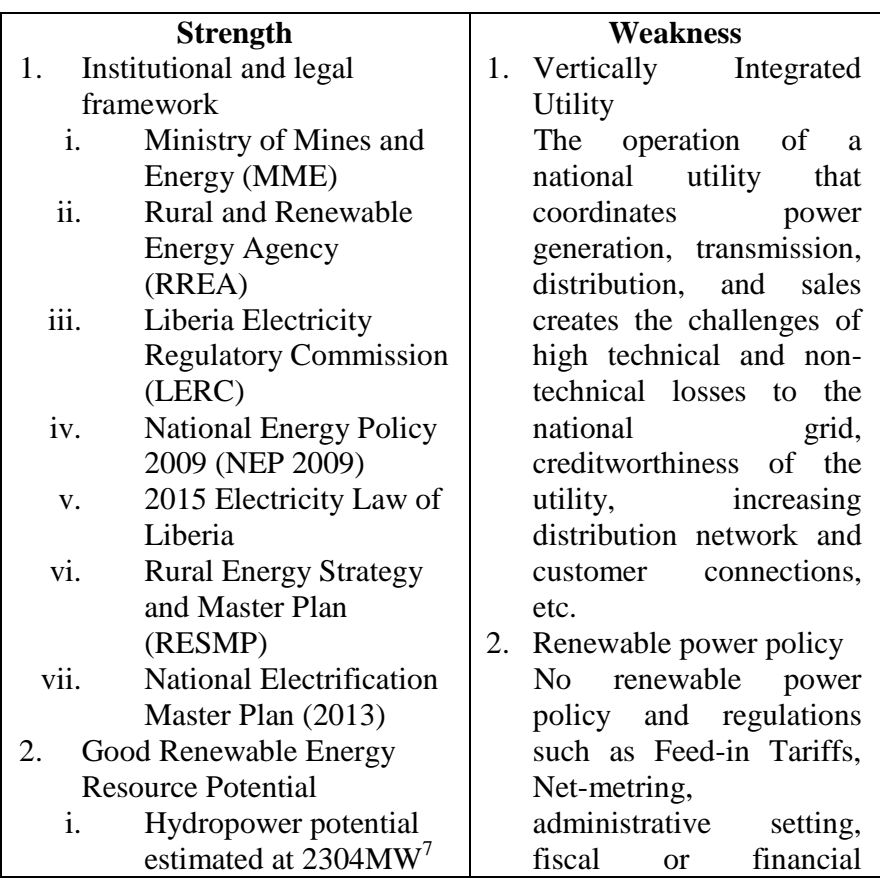

${ }^{7}$ Gesto Energy Consulting. (2016). Rural Energy Strategy and Master Plan For Liberia Until 2030 Technical Report (pp. 123124). Retrieved from

\section{Volume 10 Issue 7, July 2021}




\begin{tabular}{|c|c|}
\hline 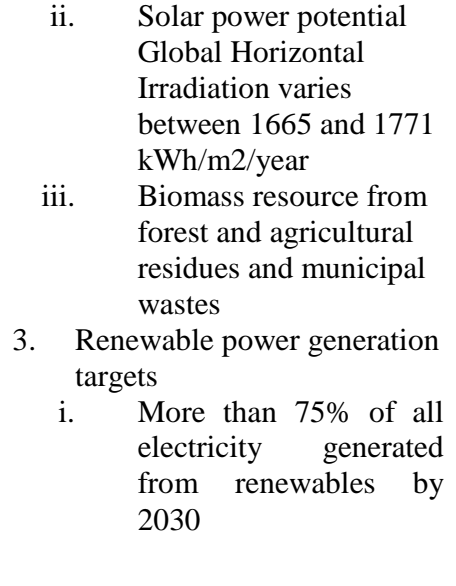 & 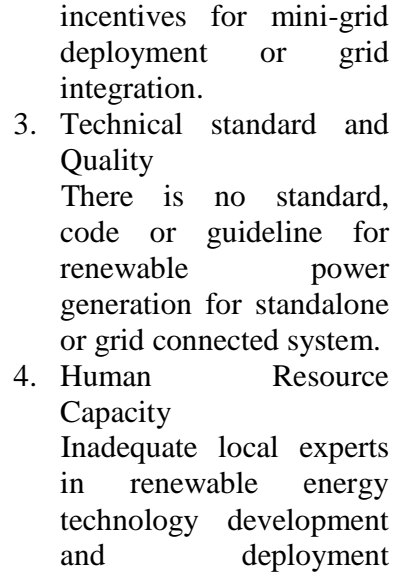 \\
\hline $\begin{array}{l}\text { Opportunities } \\
\text { 1. International donor supports } \\
\text { The financing of } \\
\text { renewable power } \\
\text { generation projects is } \\
\text { from international } \\
\text { development } \\
\text { organizations such as } \\
\text { the World Bank, } \\
\text { African Development } \\
\text { Bank, European Union, } \\
\text { United State Agency for } \\
\text { International } \\
\text { Development, etc. } \\
\text { Sub-regional power project } \\
\text { The Côte d'Ivoire, } \\
\text { Liberia, Sierra Leone } \\
\text { and Guinée (CLSG) } \\
\text { interconnection sub- } \\
\text { regional power project } \\
\text { will facilitate the } \\
\text { expansion of the } \\
\text { national grid and } \\
\text { increase electricity } \\
\text { access. }\end{array}$ & $\begin{array}{l}\text { Threats } \\
\text { 1. Long-term international } \\
\text { donor funding } \\
\text { constrains } \\
\text { i. Nearly all } \\
\text { renewable power } \\
\text { projects developed } \\
\text { in Liberia have } \\
\text { funding from } \\
\text { international } \\
\text { development } \\
\text { institutions; if } \\
\text { policy and } \\
\text { regulations are not } \\
\text { in place for public- } \\
\text { private } \\
\text { partnerships; the } \\
\text { long-term } \\
\text { development in the } \\
\text { sector will be a } \\
\text { challenge when } \\
\text { public funding } \\
\text { plummets. } \\
\text { Forest conversation } \\
\text { actions } \\
\text { International } \\
\text { supports for } \\
\text { Liberia Reducing } \\
\text { Emissions from } \\
\text { Deforestation and } \\
\text { Forest Degradation } \\
\text { (REDD+) program } \\
\text { and environmental } \\
\text { conservation } \\
\text { programs might } \\
\text { obstruct the } \\
\text { deployment of } \\
\text { large-scale solar } \\
\text { projects due to } \\
\text { Liberia } \\
\text { biodiversity, which } \\
\text { accounts for 43\% } \\
\text { of the remaining } \\
\text { Upper Guinea } \\
\text { forests of West } \\
\text { Africa. }{ }^{8} \text {. } \\
\text { 2. }\end{array}$ \\
\hline
\end{tabular}

http://liberiaruralenergy.org/sites/default/files/B - Technical Report/0. TECHNICAL REPORT - LR 2016 R 001 3.pdf ${ }^{8} \mathrm{https}: / / \mathrm{www}$. forestcarbonpartnership.org/country/liberia

\subsection{Recommendations}

The National Energy Policy, the 2015 Electricity Law, and the Rural Energy Strategy and Master Plan are the priority policy and regulations for electricity generation in Liberia. The country needs to develop and enact a Renewable Energy Law in addition to supportive policies and regulations to promote renewable power generation and private sector participation. Besides, these legal instruments do not provide clear procedures for the electrification operator models (utility, private, community, and hybrid models) and the participation of private investment in the electricity sector. Notwithstanding, the adoption of the following policy and regulatory recommendations will increase renewable power development and deployment in Liberia that will attract private investment in the electricity sector and support universal electricity access. These recommendations support the deployment of feasible renewable energy technologies (hydropower, solar, biomass, etc.) for grid-connected and off-grid power generation in Liberia.

Renewable Energy Law: The immediate step to create an enabling environment for private sector investment in the renewable power deployment and electricity sector of Liberia is to establish the renewable energy law proposed in the National Energy Policy (NEP). The new renewable energy law will establish the legal and institutional framework for national planning, implementation, and the administration of regulations for the Rural Energy Strategy and Master Plan (RESMP), integration of variable renewable power to the grids, and mini-grids developments. The proposed law will have the terms and conditions for renewable power policy and regulation such as feed-in tariff, net-metering/billing, auction/tendering, legal provision and concession agreements, fiscal and financial measures, etc.

Policy and Regulation on Tariff Setting: Tariff setting and regulations play a significant role for private investment in the electricity sector and the deployment of renewable energy technologies. Besides, the tariff regulations are essential for mini-grid investment for a nascent renewable electricity market like Liberia. Ranked amongst the countries with the highest national electricity tariff in the world, a well-designed cost-reflective tariff such as negotiated, approved, or calculated tariff and connections fees will create the market for private sector investment in the mini-grid sector of Liberia. Besides, realistic tariff FiTs setting for utility-scale renewable power generation with the prospect for returns on investments will attract private investors.

Fiscal Policy: The current electricity market structure of Liberia has the potential to stimulate private investment through fiscal policy and regulations measures such as import duties, incentives, low taxes, and accelerated depreciation charges. The design, implementation, and coordination of these fiscal measures with the massive international development support for renewable power generation in Liberia will not only provide universal energy access but a competitive electricity market. Besides, fiscal policy measures buttress government plans and strategy for 
renewable power generation where financial allocation is a constrain.

Financial Policy: Due to the high perceived risks associated with developing countries' renewable power market, the initial capital investment is a challenge for most private investment and creates financing constraints from lenders. Financial schemes such as soft-loan, grants, subsidies, incentives, and budget allocations enable affordable electricity services for grid-connected and offgrid end-users and return on investment for private investors. The established Rural Energy Fund (REFUND) provides capacity building, project and consumer finance, and risk management for renewable energy technologies deployment in Liberia.

Administrative and Legal Provisions: because private investors and financiers are attracted concerned about the long-term cash flow of an investment, clear, concise, and stable legal instruments are among the risk factors considered for renewable power generation. Hence, it is imperative to have a streamline of policy and regulations such as permits or licenses for electricity generation, distribution, and sale; concession schemes for mini-grid investment, distribution asset and electricity sale, and power purchase agreement between private investor and utility for large scale renewable power generation.

Technical Standards: adopting technical standards are essential for public safety, customer protection, power grid reliability, and stability. It is imperative to develop minimum technical standards for the integration of renewable power grid and the operation of mini-grid (isolated, hybrid, and interconnected) under the national utility standard. Similarly, technical standards for the quality of products are paramount for public trust in renewable energy technologies.

\section{Conclusions and Scope of Further Work}

With ambitious targets for renewable power generation, Liberia has the fundamental legislation and institutional framework to attract private investment in the electricity sector. However, supportive policy and regulations are needed to develop investor confidence, minimize investor risks, and guarantee returns on investment. However, a comprehensive review and analysis of the energy policy and legislation in Liberia revealed that country does not have policies and regulations for renewable power generation. Undisputedly, investment in renewable power generation needs stable, market-oriented, concise, and explicit policies and regulations. This research paper recommends policy and regulatory measures to increase generation capacity in renewable energy technologies and private sector participation. The recommendations consider the review and analysis of renewable power policies and regulations in Ghana, Nigeria, Sierra Leone, and implementation data for countries in West Africa. Conclusively, this paper recommends the establishment of the new renewable energy law and supportive policies such as policy and regulation on tariff setting, fiscal policy, financial policy, administrative and legal provision, and technical standards. Future works on this research paper will focus on the development of appropriate mechanisms to act on each of the recommendations.

\section{References}

[1] Wei-Ming, C., Hana, K., \& Hideka, Y. (2014). Renewable energy in eastern Asia: Renewable energy policy review and comparative SWOT analysis for promoting renewable energy in Japan, South Korea, and Taiwan. Energy Policy Elsevier, 74(C), 319-329. doi:10.1016/j.enpol.2014.08.019

[2] MoFA (2015). 2015 Electricity Law of Liberia. Monrovia, Liberia: Ministry of Foreigh Affairs. Retrieved from https://www.rrealiberia.org/forest/doc_download/2015\%20E lectricity\%20Law\%20of\%20Liberia.pdf

[3] ADB. (2018). CAMBODIA Energy Sector Assessment, Strategy, and Road Map. ASIAN DEVELOPMENT BANK. ASIAN DEVELOPMENT BANK. Retrieved from https://www.adb.org/sites/default/files/institutionaldocument/479941/cambodia-energy-assessment-roadmap.pdf

[4] Bernard, T., Greacen, C., \& Vaghela., D. (2018). Mini Grids and the Arrival of the Main Grid: Lessons from Cambodia, Sri Lanka, and Indonesia. World Bank. Washington, DC: Energy Sector Management Assistance Program (ESMAP). Retrieved from https://openknowledge.worldbank.org/bitstream/handle/1098 6/29018/134326.pdf?sequence=6\&isAllowed $=\mathrm{y}$

[5] Climatescope. (2020). Sub-Saharan Africa Market Outlook 2020. Climatescope BloombergNEF. Retrieved from https://global-

climatescope.org/assets/data/docs/updates/2020-02-06-subsaharan-africa-market-outlook-2020.pdf

[6] Couture, T. D., Cory, K., Kreycik, C., \& Williams, E. (2010). A Policymaker's Guide to Feed-in Tariff Policy Design. Department of Energy. Washington, D.C: National Renewable Energy Laboratory. Retrieved from https://www.nrel.gov/docs/fy10osti/44849.pdf

[7] ECOWAS. (2003). ECOWAS ENERGY PROTOCOL A/P4/1/03. Dakar: ECOWAS. Retrieved from https://www.ecowapp.org/sites/default/files/eprotocol.pdf

[8] ECREEE. (2013). ECOWAS Renewbale Energy Policy $(E R E P)$. Abuja: ECOWAS Centre for Renewable Energy and Energy Efficiency (ECREEE). Retrieved from http://www.ecreee.org/sites/default/files/documents/ecowas_ renewable_energy_policy.pdf

[9] Elavarasan, R. M., Afridhis, S., Vijayaraghavan, R., Subramaniam, U., \& Nurunnabi, M. (2020). SWOT analysis: A framework for comprehensive evaluation of drivers and barriers for renewable energy development in significant countries. Energy Reports, 1838-1864. doi:https://doi.org/10.1016/j.egyr.2020.07.007

[10] Energy Commission. (2015). NET METERING SUB-CODE for Connecting Renewable Energy Generating Systems to the Distribution Network in Ghana. Accra: Energy Commission. Retrieved from http://energycom.gov.gh/files/Net\%20Metering\%20SubCode\%2C\%202015.pdf

[11] ESMAP. (2018). Regulatory Indactor for Sustanable Energy. Washington, DC:: Energy Sector Managemnt Program (ESMAP). Retrieved from https://www.worldbank.org/en/topic/energy/publication/rise2018

[12] GESTO. (2016). Rural Energy Strategy And Master Plan for Liberia Until 2030. Monrovia Liberia: Rural and Renewable Energy Agency. doi:https://gestoenergy.com/wpcontent/uploads/2018/04/LIBERIA-RURAL-ENERGYSTRATEGY-AND-MASTER-PLAN.pdf

[13] Gurel, E., \& Tat, M. (2017). SWOT ANALYSIS: A THEORETICAL REVIEW. The Journal of International

\section{Volume 10 Issue 7, July 2021}


Social Research , 10(51). Retrieved from http://sosyalarastirmalar.com/cilt10/sayi51_pdf/6iksisat_ka mu_isletme/gurel_emet.pdf

[14] IRENA. (2018). IRENA Planning and Prospects for Renewable Power: West Africa. International Renewable Energy Agency. Abu Dhabi: International Renewable Energy Agency. Retrieved from https://www.irena.org/publications/2018/Nov/Planning-andprospects-for-renewable-power

[15] Kamran, M., Fazal, M. R., \& Mudassar, M. (2019). Towards empowerment of the renewable energy sector in Pakistan for sustainable energy evolution: SWOT analysis. Renewable Energy, 146, 543-558. doi:https://doi.org/10.1016/j.renene.2019.06.165

[16] NEP. (2009). National Energy Policy an Agenda for Action And Economic And Social Development. Monrovia. Retrieved from http://www.moci.gov.lr/doc/National\%20Energy\%20Policy $\% 202009 . p d f$

[17] NERC. (2015). Regulations On Feed-in Tariff for Renewable Energy Sourced Electricity in Nigeria . Nigerian Electricity Regulatory Commission,, Lagos, Nigeria. Retrieved from https://www.lse.ac.uk/GranthamInstitute/wpcontent/uploads/laws/2027.pdf

[18] (2016). Nigerian Electricity Regulatory Commission. NIGERIAN ELECTRICITY REGULATORY COMMISSION. Lagos, Nigeria: NIGERIAN ELECTRICITY REGULATORY COMMISSION. Retrieved from http://rea.gov.ng/wpcontent/uploads/2018/07/NERC-Mini-Grid-Regulation.pdf

[19] NREEEP. (2014). National Renewable Energy and Energy Efficiency Policy (NREEEP). Lagos, Nigeria: Energy Commission of Nigeria doi:https://www.energy.gov.ng/Energy_Policies_Plan/naton al_renewable_energy_and_energy_efficiency_policy.pdf

[20] Pikk, P., \& Viiding, M. (3 June 2014). The dangers of marginal cost based electricity pricing. Baltic Journal of Economics, pp. 49-62. Retrieved from https://www.tandfonline.com/doi/abs/10.1080/1406099X.20 13.10840525

[21] PURC. (2016). Feed-in-Traiffs for Electricity Genertaed from Renewable Energy Sources. Accra: Public Utilities Regulatory Commission. Retrieved from http://purc.com.gh/purc/sites/default/files/fit_2016.pdf

[22] PWC. (November 2017 ). Power in Indonesia . Indonesia: PWC. Retrieved from https://www.pwc.com/id/en/energyutilities-mining/assets/power/power-guide-2017.pdf

[23] REA. (2011). Renewable Energy Act. Public Utilities Regulatory Commission . Accra: Public Utilities Regulatory Commission. Retrieved from http://www.purc.com.gh/purc/sites/default/files/renewable_e nergy_act_2011_act_832.pdf.pdf

[24] REN21. (2019). Renewables 2019 Global Status Report. REN21 Secretariat. Paris: REN21. Retrieved from https://www.ren21.net/wpcontent/uploads/2019/05/gsr_2019_full_report_en.pdf

[25] SLEWRC. (2018). Sierra Leone Electricity and Water Regulatory Commission Mini-Grid Regulations, 2018. Freetown: Sierra Leone Electricity and Water Regulatory Commission. Retrieved from https://ewrc.gov.sl/wpcontent/uploads/2018/12/Mini-Grid-Regulations-2018-1.pdf

Volume 10 Issue 7, July 2021 www.ijsr.net 